\title{
Covid-19 Pandemi Döneminde Korku Öğesi Barındıran ve Virüsten Korunma Temalı Reklamların Satın Alma Niyeti ve Reklama Yönelik Tutum Üzerindeki Etkileri
}

\section{The Effects of Fear Appeal and Protecting to Virüs Themed Ads on Purchase Intention and Attitude Towards Advertising During the Covid-19 Pandemic Period}

\author{
İbrahim Aydın*
}

\begin{abstract}
Öz: Bu çalışmanın başlıca amacı Covid-19 pandemi döneminde korku öğesi barındıran ve televizyonda çıkan virüsten korunma temalı reklamların satın alma niyeti ve reklama yönelik tutum üzerinde meydana getirdiği etkileri araştırmaktır. Araştırmanın hedef kitlesini bu tür reklamlar ile karşılaşmış kişiler oluşturmaktadır. Çevrimiçi olarak gerçekleştirilen anket çalışmasına katılan 756 kişiden elde edilen verilerle araştırma gerçekleştirilmiştir. Bu çalıma için, Van Yüzüncü Yıl Üniversitesi Sosyal ve Beşeri Bilimleri Bilimsel Araştırmalar Yayın Etik Kurulu'nun 22.10.2020 tarih ve 2020/12-02 nolu kararı ile çalışmanın etik kurallara uygun olduğuna dair gerekli izin alınmıştır. Çalışmanın bağımsız değişkenleri demografik özellikler iken bağımlı değişkenleri ise satın alma niyetine etki ve reklama yönelik tutumdur. Çalışmada bu tür reklamların reklama yönelik tutumda ve satın alma niyetinde bir farklılığa neden olup olmadığı, ayrıca demografik özelliklerin reklama yönelik tutumda ve satın alma niyetinde bir farkl1lığa neden olup olmadığı araştırılmıştır. Elde edilen sonuçlara göre bu tür reklamların reklama yönelik tutumda ve satın alma niyetinde olumlu yönde etkisinin olduğu; cinsiyet, yaş ve medeni durum değişkenlerine göre anlamlı bir farklılığa rastlanmadığı, ilköğretim mezunlarının lisans ve lisansüstü eğitim alan kişilere göre reklama yönelik tutumda daha olumlu etkilendikleri anlaşılmıştır. Elde edilen verilerin çözümlenmesinde tek yönlü MANOVA, tek faktörlü ANOVA ve tek örneklem t testi kullanılmıştır.
\end{abstract}

Anahtar Kelimeler: Covid-19, Korku Öğesi, Satın Alma Niyeti, Reklama Yönelik Tutum

\begin{abstract}
The main purpose of this study is to investigate the effects of the fear appeal and protecting to virüs themed advertisements on the purchase intention and attitude towards advertising during the Covid-19 pandemic period. The target audience of the research consists of people who have encountered such advertisements. The research was carried out with the data obtained from 756 people who participated in the online survey. For this study, the necessary permission was obtained with the decision of the Social and Human Sciences Scientific Research Publication Ethics Committee of Van Yüzüncü Y1l University, dated 22.10.2020 and numbered 2020/1202 . While the independent variables of the study are demographic characteristics, the dependent variables are the effect on purchase intention and attitude towards advertising. In the study, it was investigated whether such advertisements cause a difference in attitude towards advertising and purchase intention, and also whether demographic characteristics cause a difference in attitude towards advertising and purchase intention. According to the results, such advertisements have a positive effect on the attitude towards advertising and purchase intention; it was understood that there was no significant difference in terms of gender, age and marital status variables, but primary school graduates were more positively affected by the attitude towards advertising than those who
\end{abstract}

\footnotetext{
* Dr. Öğr. Üyesi, Van Yüzüncü Y1l Üniversitesi, Erciş İşletme Fakültesi, İşletme Bölümü ORCID: 0000-0002-0720-364X, aydnibrhm@ hotmail.com
}

Received/Geliş: 1 Kasım/November 2020 Accepted/Kabul: 29 March/Mart 2021
Düzeltme/Revised form: 20 March/Mart 2021

Published/Yayın: 31 August/Ağustos 2021

e-ISSN: 2149-4622. ( ) 2013-2019 Muş Alparslan Üniversitesi. TÜBİTAK ULAKBİM DergiPark ev sahipliğinde. Her hakk1 saklıdır. http://dx.doi.org/10.18506/anemon.819277 
received undergraduate and postgraduate education. One-way MANOVA, one-factor ANOVA and one-sample $\mathrm{t}$ test were used to analyze the data obtained.

Keywords: Covid-19, Fear Appeal, Purchase Intention, Attitude Towards Advertising

\section{Giriş}

2019'un sonlarında Çin'in Vuhan kentinde ortaya çıkan yeni koronavirüs hastalığı (Covid-19), kısa sürede tüm dünyaya yayılarak Dünya Sağl1k Örgütü tarafından 11 Mart 2020 tarihinde pandemi olarak ilan edilmişti. Covid-19 pandemisi, sağlıktan eğitime, ekonomiden yasal ve idari düzenlemelere kadar tüm alanlarda etkisini hissettirerek, insanların sosyal hayatlarında, psikolojilerinde, tüketim alışkanlıklarında ve hemen her şeyde farklılıklara neden olmuştu. Artık insanlar daha fazla evde oturarak, daha seyrek alış verişe çıkarak, daha çok internetten ürün sipariş vererek, özellikle pandeminin ilk dönemlerinde dayanıklı gıda stoklayarak, takviye gıdalar, sağlıklı yiyecekler, virüsten korunma amaçlı dezenfektan, kolonya, temizlik ürünleri, maske gibi ürünleri daha fazla satın alarak bunun aksine giysi, motorlu araçlar, konaklama hizmetleri, seyahat, eğlence, hazır gıda gibi ürünleri daha az satın alarak oldukça farklı bir şekilde yaşamaya ve tüketim alışkanlıklarına başlamıştılar. Haliyle bu farklı yaşam, tüketim alışkanlıkları ve değişen makro-mikro çevresel faktörler, pazarlama faaliyetlerinin de daha farklı bir şekilde icra edilmesine neden olmuştu. Virüsten korumaya yarayan veya bünyeyi güçlendiren ürünler öncesine göre çok daha fazla üretilmişti. Dağıtım faaliyetleri müşterilerin ve çalışanların virüse yakalanma riskini en aza indirmek suretiyle yerine getirilmişti. Fiyat farklı ürünler için değişen arz-talep dengesine ve yasal, idari düzenlemelere göre belirlenmişti. Pazarlama iletişimi faaliyetleri ise virüsten korunma ve sağlıklı ürün temaları işlenerek yerine getirilmişti. Reklamlarda virüsten korunma amaçlı ürünler sıkça konu edinilmişti.

İşletmeler tarafindan hedef kitleleri ile kurulan iletişimin daha etkin ve verimli olabilmesi için farklı reklam türleri denenmiştir (Aydın, 2020: 234). Bu türlerden biri reklamda korku öğelerinin kullanılmasıdır. Korku uyandıran mesajlar insanları bir sorun hakkında daha dikkatli düşünmeye motive edebilir (Sanbonmatsu ve Kardes, 1988: 384). Korku öğeleri, farklı pazarlama iletişimi türlerinde yaygın olarak kullanılmaktadır (Williams, 2012: 4). Örneğin; malların, hizmetlerin, sosyal sorunların ve fikirlerin pazarlanmasında yaygın olarak kullanılır. Bu reklamlardaki ana mesaj: eğer reklamda verilenleri yapmazsanız (satın almak, desteklemek, öğrenmek, inanmak, kullanmak gibi) bunun istenmeyen sonuçlara neden olacağıdır (Glascoff, 2000: 35). Korku öğeleri sağlık kampanyalarında oldukça sık kullanılmaktadır (Hastings vd., 2004: 961). Reklamlarda da insan sağlığını ilgilendiren konularda korku öğeleri siklıkla kullanılır (Shimp ve Andrews, 2013: 299). Covid-19 pandemi döneminde insan sağlığının tehdit altında olduğu şeklindeki konular reklamlarda işlenerek firmalar tarafından korku öğelerine sıkça başvurulmuştu. Pandemi döneminde bu deterjanı, dezenfektanı veya ıslak mendili kullanırsanız virüsten korunabilirsiniz, eğer kullanmazsanız virüse yakalanma riskiniz artar, şeklinde korku öğesi barındıran çok sayıda reklama çeşitli mecralarda neredeyse tüm tüketiciler maruz kalmıştı. İnsanların pandemi döneminde daha fazla evde vakit geçirmeleri ile birlikte, televizyon izleme oranı artmış ve bununla birlikte insanlar daha fazla televizyon reklamlarına maruz kalmışlardı. $\mathrm{Bu}$ çalışmanın amacı, Covid-19 pandemi döneminde televizyonda verilen virüsten korunma temalı reklamların satın alma niyeti ve reklama yönelik tutum üzerinde nasıl etkilere neden olacağını araştırmaktır. Bu etkiler araştırılırken cinsiyet, yaş, eğitim durumu ve medeni durum değişkenleri göz önüne alınarak, demografik farklılıklar arasında herhangi bir farklılığın olup olmadığı da incelenecektir. Covid-19 pandemisinin iş dünyasını, pazarlama faaliyetlerini, dünyadaki hemen her şeyi ve tüm insanların hayatını dramatik bir şekilde etkilemesi ile birlikte, böyle bir dönemde virüsten korunma amaçlı ve korku öğesi barındıran reklamların satın alma niyeti ve reklama yönelik nasıl etkilerde bulunduğunun araştırılması literatüre ve iş dünyasına önemli katkılarının olacağı düşünülmektedir. Ayrıca literatür detaylı bir şekilde incelenmiş ve Covid-19 döneminde korku öğesi barından ve virüsten korunma temalı reklamların satın alma niyetine ve reklama yönelik tutuma olan etkilerini araştıran bir çalışmaya rastlanmamıştır. Böyle bir çalışmanın ilk kez gerçekleştirilmesi çalışmayı ayrıca daha değerli kılacağı düşünülmektedir. 


\section{Literatür ve Hipotezler}

İnançlar üç şekilde oluşturulabilir. Deneyim ve gözlem, dış kaynaklardan gelen bilgi ve çıkarım süreçleri ile inançlar oluşturulur. İnançlar ise insanların bir objeye yönelik tutumlarını belirler. $\mathrm{Bu}$ tutumlar daha sonra o objeye yönelik doğrudan bir davranışa neden olacak niyetlere yol açar. Reklam bir tüketicinin satın alma niyetine ve satın alma kararına neden olan inanç ve tutumların oluşmasını etkileyen bir dış bilgi kaynağıdır (Jovanović vd., 2016: 35-36). Daha güçlü korku öğeleri daha fazla tutum, niyet ve davranış değişikliğine neden olur (Witte ve Allen, 2000: 598). Korku öğeleri içeren reklamların ikna edici olduğuna dair birçok çalışma vardır (Hastings vd., 2004: 978; Insko vd., 1965: 261; Dillard vd., 1996: 68; Tannenbaum vd., 2015: 1198; Siu, 2010: 580; Terskikh, 2017: 160; Bagozzi ve Moore, 1994: 66; Leventhal vd., 1966: 394-395; Lewis vd., 2007: 55-56; Bleakley vd., 2015: 943; Smith ve Stutts, 2003: 172; Smith ve Stutts, 2006: 281; Treise ve Weigold, 2001: 54; Bigsby vd., 2013: 11-12). Bazı çalışmalarda ise bu tür reklamların ikna edici olmadığı sonucuna ulaşılmıştır (Jovanović, 2016: 41; Kim ve Lee, 2012: 14; Ti vd., 2017: 3).

Snipes ve arkadaşlarının 305 kadın üzerinde gerçekleştirdikleri çalışmalarında, çalışmaya katılanlara düşük derecede korku öğeleri veya yüksek derecede korku öğelerinden birini içeren reklam izlettirildi. Reklamlardan birini izleyen katılımcılar, satın alma niyetinin belirlenebilmesi için anket doldurmuştu. Sonuçlara bakıldığında yüksek derecede korku öğeleri içeren reklamları izleyen katılımcıların, düşük derecede korku öğelerini izleyenlere göre daha fazla satın alma niyetinde oldukları ortaya çıkmıştı (1999: 280). Dolayısıyla, bu ürünü satın almazsanız virüse yakalanma riskiniz artar veya bu ürün virüse yakalanma riskinizi azaltır şeklinde mesaj veren reklamların, satın alma niyetinde olumlu etkiye sahip olduğu düşünülmektedir. Bu bilgiler bağlamında aşağıdaki hipotez oluşturulmuştur:

H1. Korku öğesi bulunduran reklamların satın alma niyeti üzerinde olumlu etkisi vardır.

Cinsiyet değişkenine göre satın alma niyetinde herhangi bir farklılı̆̆ın olup olmadığının anlaşılması, çalışmanın başlıca amaçlarından birini oluşturmaktadır. Literatüre bakıldığında bazı çalışmalarda korku öğesi barındıran reklamların kadınlara göre erkeklerde daha ikna edici olduğu sonucuna varılmıştır (Treise ve Weigold, 2001: 54; Smith ve Stutts, 2006: 289; Aydın ve Y1ldırım, 2020: 37). Smith ve Stutts'un çalışmasında ise ikna edicilik konusunda kadınlar ile erkekler arasında herhangi bir farka rastlanmamıştır (2003: 171). Fakat çoğu çalışmada bu tür reklamların erkeklere göre kadınlarda daha ikna edici olduğu sonucuna varılmıştır (Leventhal vd., 1966: 394-395; Tannenbaum vd., 2015: 1196; Goldenbeld vd., 2008: 213; Lewis 2007: 55-56; Samu ve Bhatnagar, 2008: 242; Smith ve Stutts, 2003: 171; Bigsby vd., 2013: 11-12).

Negatif mesaj cezbedicileri olarak kullanılan korku ve suçluluk cezbedicileri reklam bağlamında benzer özellikler göstermektedir (Noble vd., 2014: 6). Noble ve arkdaşları negatif mesaj cezbedicilerinden olan suçluluk temalı bir reklamı katılımcılara gösterdikten sonra uyguladıkları anket çalışması sonucunda, satın alma niyeti için kadınların erkeklere göre daha olumlu görüş bildirdikleri sonucuna ulaşmışlardır (2014: 13). Elde edilen bilgiler neticesinde aşağıdaki hipotez ortaya konmuştur:

H2. Korku öğesi bulunduran reklamların erkeklere kıyasla kadınların satın alma niyeti üzerinde daha fazla olumlu etkisi vardır.

Snipes ve arkadaşlarının gerçekleştirdikleri çalışmalarında, yüksek derecede korku öğeleri içeren reklamları izleyen katılımcıların, düşük derecede korku öğelerini izleyenlere göre reklama yönelik tutumda daha olumlu şekilde etkilendikleri ortaya çıkmıştı (1999: 280). Jovanović ve arkadaşlarının fokus (odak) grup görüşmesi şeklindeki çalışmalarında katılımcılara izletilen korku öğesi taşıyan bir reklam filmi sonrasında katılımcılar bu reklam filminden olumsuz şekilde etkilendiklerini belirtmişlerdir (2016: 41). Feiz ve arkadaşlarının 384 kişinin katılımıyla İran'da gerçekleştirilen çalışmalarında, aralarında korku öğesinin de olduğu duygusal çekicilik öğeleri barındıran televizyon reklamlarının reklama yönelik olumlu tutumlara neden olduğu sonucuna ulaşmışlardır (2013: 116). Araştırma firması Lumen tarafından yapılan bir araştırmaya göre Covid-19 virüsü ile ilişkili olan reklamlar \%9 oranında daha fazla dikkat çekmiştir (https://www.lumen-research.com/blog/corona-related-ads-get-9-more- 
attention). Literatürden görüldüğü üzere daha fazla çalışmada korku öğesi barındıran reklamların, reklama yönelik daha olumlu bakılmasına neden olduğu sonucuna ulaşıldığı anlaşılmaktadır. Covid-19 döneminde virüsten korunma temalı reklamların daha fazla dikkat çekeceği de göz önüne alındığında bu tür reklamlara yönelik tutumun olumlu yönde olacağı düşünülmektedir.

H3. Korku öğesi bulunduran reklamların reklama yönelik tutum üzerinde olumlu etkisi vardır.

Çalışmanın bir diğer amacını oluşturan reklama yönelik tutumda cinsiyet değişkenine göre bir farklılığın olup olmadığg ile ilgili ulaşılan çalışmalar şunlardır: Tannenbaum ve arkadaşlarının meta analiz şeklinde yaptıkları çalışmada, tutum değişkeninde korku öğesi barındıran reklamların erkeklere göre kadınlarda daha etkili olduğu sonucuna varılmıştır (2015: 1196). Smith ve Stutts'un gerçekleştirdikleri çalışmada, korku öğesi barındıran reklama yönelik tutumda erkek ve kadınlar arasında herhangi bir farka rastlanılmamıştır (2003: 171). Noble ve arkadaşları negatif mesaj cezbedicilerinden olan suçluluk temalı bir reklamı katılımcılara gösterdikten sonra uyguladıkları anket çalışması sonucunda, erkeklerin kadınlara göre bu reklamlardan daha olumlu yönde etkilendiklerini bildirmişlerdir (2014: 13). Goldenbeld ve arkadaşlarının korku öğesi barındıran hızlı araba kullanmanın risklerini ele alan kamu spotlarının etkilerini araştırdıkları çalışmalarında, kadınların erkeklere göre bu kamu spotlarından daha fazla olumlu yönde etkilendikleri sonucuna ulaşılmıştır (2008: 213). Verilen bu bilgilere istinaden aşağıdaki hipotez meydana getirilmiştir:

H4. Korku öğesi bulunduran reklamların erkeklere kıyasla kadınların reklama yönelik tutumunda daha fazla olumlu etkisi vardır.

\section{Veri Toplama Araçları ve Veri Toplama Süreci}

Çalışmada virüsten koruma temalı reklamların satın alma niyeti ve reklama yönelik tutumu nasıl etkilediğini tespit edebilmek amacıyla, satın alma niyetine ve reklama yönelik tutum alt ölçekleri zıt sıfatlardan (bipolar adjectives) teşkil edilmiş olan yedili Likert ölçeği şeklinde meydana getirilmiştir. İki ölçeğin de Türkçeye adaptasyonu Pornpitakpan ve Yuan'ın kullandıkları ölçeklerden faydalanılarak yapılmıştır (2015: 541-542).

Çalışmada kullanılacak veriler internet üzerinden anket doldurulması suretiyle elde edilmiştir. 872 kişi anket çalışmasına katılmış ve bu kişilerden $115(\% 13,2)$ kişi Covid-19 pandemi döneminde televizyonda çıkan reklamlarda korku öğesi barındıran ve virüsten korunma temalı reklamlar ile karşılaşmadıklarını belirttiklerinden bu kişilerin doldurduğu anketler ve uç değer olarak saptanan 1 anket çalışmadan çıkarılarak 756 anket formu çalışmada kullanılmıştır.

T.C. Van Yüzüncü Yıl Üniversitesi Sosyal ve Beşeri Bilimleri Bilimsel Araştırmalar Yayın Etik Kurulu'nun 22.10.2020 tarih ve 2020/12-02 nolu kararı ile çalışmanın etik kurallara uygun olduğuna karar verilmiştir.

\section{Evren ve Örneklem}

Bu çalışmanın hedef kitlesini Türkiye'de yaşayan ve Covid-19 Pandemi döneminde televizyonda çıkan korku öğesi barındıran ve virüsten korunma temalı reklamlara maruz kalmış kişiler oluşturmaktadır. Anket formunun linki sosyal medya uygulamalarından biri olan Whatsapp aracılığı ile Türkiye'de yaşayan çok sayıda kişiye gönderilmiş ve gönderilen kişilerin de tanıdıklarına göndermeleri rica edilmiştir. Çalışmanın örneklemini kartopu örnekleme yöntemiyle ulaşılan 756 kişi oluşturmaktadır. Krejcie ve Morgan'ın kullandıkları formüle göre, Türkiye nüfusunu evren olarak ele aldığımızda 83154997 kişi için 756 kişilik örneklem \%95 üzerinde güven düzeyi sağlayacaktır (1970: 608).

Katılımcılar ile ilgili demografik bilgiler Tablo 1'de verilmiştir. 


\begin{tabular}{ccc}
\multicolumn{3}{c}{ Tablo 1. Katılımcılar ile İlgili Demografik Bilgiler } \\
\hline Cinsiyet & Frekans & Yüzde \\
Kadın & 293 & 38,8 \\
Erkek & 463 & 61,2 \\
\hline Yaş Aralıkları & Frekans & Yüzde \\
$18-23$ & 127 & 16,8 \\
$24-29$ & 163 & 21,6 \\
$30-35$ & 186 & 24,6 \\
$36-41$ & 159 & 21 \\
$42-47$ & 71 & 9,4 \\
$48-53$ & 33 & 4,4 \\
54 ve Üstü & 17 & 2,2 \\
\hline Medeni Durum & Frekans & Yüzde \\
Bekar & 274 & 36,2 \\
Evli & 482 & 63,8 \\
\hline Eğitim Durumu & Frekans & Yüzde \\
İlköğretim & 43 & 5,7 \\
Lise & 122 & 16,1 \\
Üniversite & 432 & 57,1 \\
Lisansüstü & 159 & 21 \\
\hline
\end{tabular}

\section{Geçerlilik ve Güvenilirlik Analizleri}

Çalışmada kullanılan ölçek için Cronbachs Alpha değeri ,893 bulunmuştur. Bu değere göre ölçek yüksek güvenilirliğe sahiptir.

Faktör analizi için örneklem büyüklügünün yeterli düzeyde olup olmadığını anlamak için KaiserMeyer-Olkin (KMO) değeri ve Barlett Küresellik Testi incelenmiştir. KMO değerinin ,848 ve Barlett Küresellik Testi'nin anlamlı sonuç verdiği $(\chi 2(10)=2326,861$; $p<, 001)$ görülmüştür. Buna göre veri setinin Açımlayıcı Faktör Analizine uygun olduğu anlaşılmıştır.

Temel bileşenler analizi ve eğik döndürme yöntemlerinden biri olan Direct Oblimin yöntemi kullanılarak ölçeğin faktör yapısı belirlenmiştir. Bu işlemler neticesinde toplam varyansın \%81,951'ini açıklayan 2 faktörlü bir yapıya ulaşılmıştır. Alt faktörlerin her birinin toplam varyansın \%5'inden fazlasını açıkladığı belirlenmiştir. Buna göre ölçeğin yapı geçerliliği sağlanmıştır.

\section{Verilerin Analizi}

Tüm katılımcılar göz önüne alındığında, reklama yönelik tutum ile satın alma niyetine etki bağımlı değişkenlerinde farklılık olup olmadığının belirlenebilmesi amacıyla tek örneklem $t$ testi kullanılmıştır.

Cinsiyet bağımsız değişkenin, reklama yönelik tutum ile satın alma niyetine etki bağımlı değişkenlerinde meydana getirdiği farklılıkların belirlenebilmesi amacıyla tek yönlü MANOVA analizi kullanılmıştır.

MANOVA testinin gerçekleștirilebilmesi için çok sayıda ön şart vardır (Akbulut, 2010: 156; Alpar, 2011: 204; Tabachnick ve Fidell, 2015: 279; Stevens, 2009: 217). Ön şartların yerine getirilip getirilmediğinin anlaşılması amacıyla aşağıdaki işlemler gerçekleştirilmiştir.

Örneklem büyüklüğü MANOVA testinin yapılabilmesi için gerekli olan şartlardandır. Buna göre en az bağımlı değişken sayısı kadar katılımcı olması gerekmektedir. Katılımcı sayısına bakıldığında bu şartın sağlandığı anlaşılmıştır.

Tek değişkenli normallik şartının sağlanıp sağlanmadığının anlaşılabilmesi amacıyla reklama yönelik tutum ve satın alma niyetine etki bağımlı değişkenlerinin çarpıklık-basıklık değerlerine bakılmış ve her bir değişken için -1 ile 1 arasında değerlerin olduğu anlaşılmıştır. Bu değerlere göre tek değişkenli normallik şartının sağlandığı görülmüştür. 
Çok değişkenli normal dağılım şartının sağlanıp sağlanmadığının anlaşılabilmesi amacıyla Mahalanobis uzaklık değerleri incelenmiştir. Mahalanobis uzaklıkları baz alınarak çok değişkenli uç değer analizi $(p<0,001)$ yapılmış ve Mahalanobis uzaklığı değeri $x^{2}(2)=13,816^{6}$ nın üzerinde yer alan 1 veri uç değer olarak saptanmış ve veri setinden çıkarılmıştır.

Saçılma diyagram matrislerine bakılmış, grafiklerin elips şeklinde olduğu görülmüştür. Bu nedenle, çok değişkenli doğrusallık şartının sağlandığı söylenebilir.

Tablo 2. Varyans - Kovaryans Matrisinin Homojenliği Testi

\begin{tabular}{cccccc}
\hline & Box' s M & Sd1 & Sd2 & F & P \\
\hline Değer &, 945 & 3 & 1,72 &, 314 &, 815 \\
\hline
\end{tabular}

Tablo 2'de görüldüğü gibi Box's M testi sonucunda anlaml1lık değeri 0,815 olarak bulunmuş olup varyans-kovaryans matrislerinin homojenliği şartının sağlandığı anlaşılmıştır.

Tablo 3. Hata Varyanslarının Homojenliğine İlişkin Levene F Testi Sonuçları

\begin{tabular}{lcccc}
\hline & F & Sd1 & Sd2 & P \\
\hline Reklama yönelik tutum &, 024 & 1 & 754 &, 876 \\
Satın alma niyetine etki &, 241 & 1 & 754 &, 624 \\
\hline
\end{tabular}

Hata varyanslarının homojenliği şartı için, bağımlı değişkenlerin her biri için hata varyanslarının homojenliği Levene $\mathrm{F}$ testiyle test edilmiş ve elde edilen değerler tablo 3 'te verilmiştir. İki bağımlı değişken için değerlerin anlamlı çıkmaması ile varyansların eşteşliği şartının sağlandığı anlaşılmıştır.

Çoklu doğrusal bağıntı ve tekillik koşulunun sağlanabilmesi amaciyla bağımlı değişkenler arasında korelasyon değerinin orta düzeyde olması gerekmektedir (Akbulut, 2010: 158-159). Bağımlı değişken için Pearson korelasyon testi yapılmış 0,625 ve 0,756 korelasyon değerlerine ulaşılmıştır. $\mathrm{Bu}$ değerlere göre bağımlı değişkenler arasında tekillik sorunu yoktur.

MANOVA testinin uygulanabilmesi için tüm şartların sağlandığı görülmüştür.

\section{Bulgular}

Cinsiyete göre, reklama yönelik tutumda ve satın alma niyetinde farklılık olup olmadığının anlaşılması amacıyla gerçekleştirilen MANOVA testi ile ilgili bilgiler tablo 4'te verilmiştir.

Tablo 4. Cinsiyet Değişkenine Göre Reklama Yönelik Tutum Ölçeği ve Satın Alma Niyetine Etki

Ölçeği Ortalama Puanlarına İlişkin MANOVA Testi Sonuçları

\begin{tabular}{lllccccc}
\hline Varyansın Kaynağı & Bağımlı Değişken & KT & Sd & KO & F & P & $\boldsymbol{\eta}^{\mathbf{2}}$ \\
\hline Cinsiyet & Satın Alma Niy. Etki & 2,239 & 1 & 2,239 &, 640 &, 424 &, 001 \\
& Reklama yön. tutum & 2,398 & 1 & 2,398 & 1,063 &, 303 &, 001 \\
\hline \multirow{2}{*}{ Hata } & Satın Alma Niy. Etki & 2635,962 & 754 & 3,496 & & & \\
& Reklama yön. tutum & 1701,024 & 754 & 2,256 & & & \\
\hline \multirow{2}{*}{ Toplam } & Satın Alma Niy. Etki & 2638,201 & 755 & & & & \\
& Reklama yön. tutum & 1703,422 & 755 & & & & \\
\hline
\end{tabular}

Tablo 4'te görüldüğ̈ gibi, reklama yönelik olumlu veya olumsuz yönde etkilenme düzeylerinin cinsiyet değişkeninin etkisine göre anlamlı olarak farklılaşmadığı sonucuna ulaşılmıştır (Wilks' $\Lambda=, 999$, $\left.\mathrm{F}(1,754)=1,063, \mathrm{p}>, 05, \eta^{2}=, 001\right)$.

Satın alma niyetine yönelik olumlu veya olumsuz yönde etkilenme düzeylerinin de cinsiyet değişkeninin etkisine göre anlamlı olarak farklılaşmadığı sonucuna varılmıştır (Wilks' $\Lambda=, 999, F(1$, 754) $\left.=640, \mathrm{p}>, 05, \eta^{2}=, 001\right)$.

Tüm katılımcıların reklama yönelik tutumlarının ve satın alma niyetlerinin anlaşılması amacıyla, herhangi bir demografik fark gözetilmeden bütün anketler birlikte ele alınmıştır. Reklama yönelik tutumların ve satın alma niyetlerinin anlaşılabilmesi amacıyla uygun istatistiki analiz olan tek örneklem için t-testi uygulanmış elde edilen bulgular tablo 5 ve tablo 6'da verilmiştir. 
Tablo 5. Satın Alma Niyetine Etki Ölçeğine İlişkin Tek Örneklem t Testi

\begin{tabular}{|l|c|c|c|c|}
\hline \multirow{2}{*}{ Bağımlı değiş̧ken } & \multicolumn{4}{|c|}{ Test Value: 4 } \\
\cline { 2 - 5 } & - & Sd & t & $\mathrm{P}$ \\
\hline Satın Alma Niyetine Etki & 4,15 & 755 & 2,257 &, 024 \\
\hline
\end{tabular}

Yukarıda tablo 5'ten görüleceği gibi korku öğesi barındıran ve virüsten korunma temalı reklamların, katılımcıların satın alma niyetine yönelik olumlu veya olumsuz yönde etkilenme düzeylerinde anlamlı bir farklılaşmaya neden olduğu sonucuna ulaşılmıştır $\left(\mathrm{t}_{755}=2,257, \mathrm{p}<05\right)$. Ortalama değerine bakıldığında bu farklılaşmanın olumlu yönde olduğu anlaşılmıştır.

Tablo 6. Reklama Yönelik Tutum Ölçeğine İlişkin Tek Örneklem t Testi

\begin{tabular}{|l|c|c|c|c|}
\hline \multirow{2}{*}{ Bağımlı değişken } & \multicolumn{4}{|c|}{ Test Value: 4 } \\
\cline { 2 - 5 } & - & Sd & $\mathrm{t}$ & $\mathrm{P}$ \\
& $\mathrm{X}$ & & & \\
\hline Reklama Yönelik Tutum & 4,813 & 755 & 14,885 &, 000 \\
\hline
\end{tabular}

Tablo 6'da görüleceği gibi korku öğesi barındıran ve virüsten korunma temalı reklamların, reklama yönelik olumlu veya olumsuz yönde etkilenme düzeylerinde anlamlı bir farklılaşmaya neden olduğu sonucuna ulaşılmıştır $\left(\mathrm{t}_{755}=14,885, \mathrm{p}<05\right)$. Ortalama değerine bakıldı̆̆ında bu farklılaşmanın olumlu yönde olduğu anlaşılmıştır.

Yaş, eğitim durumu ve medeni duruma göre satın alma niyetinde ve reklama yönelik tutumda herhangi bir farklılı̆̆ın olup olmadığının anlaşılması amacıyla değişkenler için uygun olan MANOVA testi gerçekleştirilmek istenmiştir. Yaş ve medeni durum değişkenlerinde MANOVA testinin gerçekleştirilmesi için tüm şartlar tutturulurken eğitim durumu değişkeninde varyans-kovaryans matrislerinin homojenliği ve varyansların eşteşliği şartlarının tutturulamadığı görülmüştür. Yaş ve medeni durum değişkenleri için MANOVA testi gerçekleştirilmiş. Eğitim durumu değişkeni için ise tek yönlü ANOVA testi gerçekleştirilmiştir.

Eğitim durumu için gerçekleştirilen Levene testi sonucunda hem satın alma niyetine etki hem de reklama yönelik tutum değişkenlerinde varyans eşteşliği şartının sağlanamadığı görülmüsşür. Eğitim durumunun satın alma niyetine olan etkisinin anlaşılabilmesi için gerçekleştirilen ANOVA testine ait bilgiler Tablo 7'de verilmiştir.

Tablo 7. Eğitim Durumu Değişkenine Göre "Satın Alma Niyetine Etki” İlişkin Bağımsız Gruplar İçin Tek Faktörlü ANOVA Testi Sonuçları

\begin{tabular}{lccccc}
\hline $\begin{array}{l}\text { Varyansın } \\
\text { kaynağı }\end{array}$ & KT & Sd & KO & F & P \\
\hline Gruplararasi & 25,348 & 3 & 8,449 & & \\
& & & & 2,432 &, 064 \\
Gruplariçi & 2612,853 & 752 & 3,475 & & \\
Toplam & 2638,201 & 755 & & & \\
\hline
\end{tabular}

Tablo 7'de görüldüğü üzere, satın alma niyetinde olumlu veya olumsuz yönde etkilenme düzeylerinin eğitim durumu değişkeninin etkisine göre anlamlı olarak farklılaşmadığı sonucuna

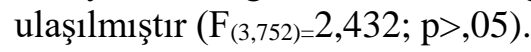

Eğitim durumunun reklama yönelik tutuma olan etkisinin anlaş1labilmesi için gerçekleştirilen ANOVA testine ait bilgiler Tablo 8'de verilmiştir. 
Tablo 8. Eğitim Durumu Değişkenine Göre "Reklama Yönelik Tutuma” İlişkin Bağımsız Gruplar İçin Tek Faktörlü ANOVA Testi Sonuçları

\begin{tabular}{cccccc}
\hline $\begin{array}{c}\text { Varyansın } \\
\text { kaynağı }\end{array}$ & KT & Sd & KO & F & P \\
\hline Gruplararası & 24,560 & 3 & 8,187 & 3,667 &, 012 \\
& & & & & \\
Gruplariçi & 1678,862 & 752 & 3,475 & & \\
Toplam & 1703,422 & 755 & & & \\
\hline
\end{tabular}

Tablo 8'de görüldüğü üzere, reklama yönelik tutumda olumlu veya olumsuz yönde etkilenme düzeylerinin eğitim durumu değişkeninin etkisine göre anlamlı olarak farklılaştığı sonucuna ulaşılmıştır

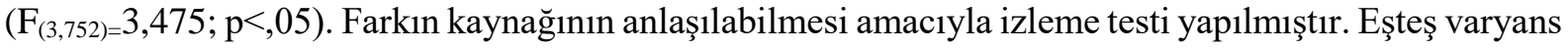
şartı yerine getirilemediğinden Tamhane's T2 değeri yorumlanmıştır. Buna göre reklama yönelik tutumda ilköğretim mezunları ve lise mezunları arasında anlamlı bir fark bulunmamıştır. Fakat ilköğretim mezunları ile lisans mezunları ve ilköğretim mezunları ile lisansüstü eğitim mezunları arasında anlamlı bir fark bulunmuştur. Ortalamalar arasındaki farklara bakıldığında; ilköğretim mezunlarının hem lisans hem de lisansüstü eğitim mezunlarına göre reklamlardan daha olumlu etkilendikleri sonucuna ulaşılmıştır. Lise, lisans ve lisansüstü eğitim mezunları arasında ise anlamlı bir farklılığa rastlanmamıştır.

Yaş değişkeninin satın alma niyetine ve reklama yönelik tutuma olan etkisinin anlaşılabilmesi için gerçekleştirilen MANOVA testine ait bilgiler Tablo 9' da verilmiştir.

Tablo 9. Yaş Değişkenine Göre Reklama Yönelik Tutum Ölçeği ve Satın Alma Niyetine Etki Ölçeği Ortalama Puanlarına İlișkin MANOVA Testi Sonuçları

\begin{tabular}{llllllll}
\hline $\begin{array}{l}\text { Varyansın } \\
\text { kaynağı }\end{array}$ & Bağımlı değişken & KT & Sd & KO & F & P & $\boldsymbol{\eta}^{\mathbf{2}}$ \\
\hline Yaş & Satın Alma Niy. Etki & 2,553 & 6 & 2,553 & 4,375 &, 626 &, 006 \\
& Reklama yön. tutum & 1,273 & 6 & 1,273 & 3,373 &, 761 &, 004 \\
\hline Hata & Satın Alma Niy. Etki & 2622,881 & 749 & 3,502 & & & \\
& Reklama yön. tutum & 1695,784 & 749 & 2,264 & & & \\
\hline Toplam & Satın Alma Niy. Etki & 2638,201 & 755 & & & & \\
& Reklama yön. tutum & 1703,422 & 755 & & & & \\
\hline
\end{tabular}

Tablo 9'dan anlaşıldığ üzere, reklama yönelik olumlu veya olumsuz yönde etkilenme düzeylerinin yaş değişkeninin etkisine göre anlamlı olarak farklılaşmadığı sonucuna ulaşılmıştır (Wilks' $\left.\Lambda=, 985, \mathrm{~F}(6,749)=3,373, \mathrm{p}>, 05, \eta^{2}=, 004\right)$.

Satın alma niyetine yönelik olumlu veya olumsuz yönde etkilenme düzeylerinin yaş değişkeninin etkisine göre anlamlı olarak farklılaşmadığı anlaşılmıştır (Wilks' $\Lambda=, 985, F(6,749)=4.375, p>, 05$, $\left.\eta^{2}=, 006\right)$.

Medeni Durum değişkeninin satın alma niyetine ve reklama yönelik tutuma olan etkisinin anlaşılabilmesi için gerçekleştirilen MANOVA testine ait bilgiler Tablo 10'da verilmiştir.

Tablo 10. Medeni Durum Değişkenine Göre Reklama Yönelik Tutum Ölçeği ve Satın Alma Niyetine Etki Ölçeği Ortalama Puanlarına İlişkin MANOVA Testi Sonuçları

\begin{tabular}{llllllll}
\hline $\begin{array}{l}\text { Varyansın } \\
\text { kaynağı }\end{array}$ & Bağımlı değişken & KT & Sd & KO & $\mathbf{F}$ & $\mathbf{P}$ & $\mathbf{\eta}^{\mathbf{2}}$ \\
\hline Medeni Durum & Satın Alma Niy. Etki & 0,22 & 1 & 0,22 &, 006 &, 937 &, 000 \\
& Reklama yön. tutum & 0,34 & 1 & 0,34 &, 015 &, 902 &, 000 \\
\hline Hata & Satın Alma Niy. Etki & 2638,179 & 754 & 3,499 & & & \\
& Reklama yön. tutum & 1703,387 & 754 & 2,259 & & & \\
\hline Toplam & Satın Alma Niy. Etki & 2638,201 & 755 & & & & \\
& Reklama yön. tutum & 1703,422 & 755 & & & & \\
\hline
\end{tabular}


Tablo 10'da görüldüğü gibi, reklama yönelik olumlu veya olumsuz yönde etkilenme düzeylerinin medeni durum değişkeninin etkisine göre anlamlı olarak farklılaşmadığ sonucuna ulaşılmıştır (Wilks' $\left.\Lambda=1,000, \mathrm{~F}(1,754)=, 015, \mathrm{p}>, 05, \eta^{2}=, 000\right)$.

Satın alma niyetine yönelik olumlu veya olumsuz yönde etkilenme düzeylerinin medeni durum değişkeninin etkisine göre anlamlı olarak farklılaşmadığı sonucuna ulaşılmıştır (Wilks' $\Lambda=1,000, F(1$, 754) $\left.=, 006, p>, 05, \eta^{2}=, 000\right)$.

\section{Sonuç, Tartışma ve Öneriler}

İş dünyası ve pazarlama profesyonelleri için oldukça önemli olan tüketicilerin reklamlara yönelik tutumu ve satın alma niyeti ile ilgili konular literatürde farklı yönleriyle birçok kez incelenmiştir (Barone ve Miniard,1999: 70-71; O'Donoghue vd., 2014: 8; Hastings vd., 2004: 978; Insko vd., 1965: 261; Dillard vd., 1996: 68; Tannenbaum vd., 2015: 1198; Siu, 2010: 580; Terskikh, 2017: 160; Bagozzi ve Moore, 1994: 66; Leventhal vd., 1966: 394-395; Baydaş ve Yaşar, 2020: 182; Neese vd., 2019: 125; Chang, 2007: 29; Jain vd., 2012: 131-132). Farklı ürünler, tüketici grupları, reklam çeşitleri ve yaşanılan koşullar gibi çok sayıda değişik faktöre göre şekillenen çalışmalar gerçekleştirilmiştir. Reklam türleri arasında olan korku öğelerinin kullanımı pazarlamacılar tarafından sıkça kullanılan bir reklam türü olmakla birlikte bu reklam türünün satın alma niyeti ve reklama yönelik tutumda tüketiciler üzerinde olan etkileri literatürde çok defa araştırılmış ve birbiriyle çelişen sonuçlara da ulaşılmıştır. Çalışmada elde edilen sonuçlar da literatürdeki bazı çalışmalar ile paralellik gösterirken (Snipes vd., 1999: 280; Hastings vd., 2004: 978; Insko, 1965: 261; Dillard vd., 1996: 68; Tannenbaum vd., 2015: 1198; Siu, 2010: 580; Terskikh, 2017: 160), bazı çalışmalar ile çelişmiştir (Jovanović, 2016: 41; Kim ve Lee, 2012: 14; Ti vd., 2017: 3).

Oldukça olağanüstü bir dönemde ve bu olağanüstü döneme sebep olan virüsün reklamlarda korku öğesi olarak kullanılmasının tüketicilerde satın alma niyetine ve reklama yönelik tutuma neden olduğu olumlu veya olumsuz yöndeki etkileri veya herhangi bir etkiye neden olmaması şeklindeki sonuçlara ulaşmanın birçok açıdan oldukça değerli olduğu düşünülmektedir.

Elde edilen sonuçlara göre korku öğesi bulunduran reklamların satın alma niyeti üzerinde olumlu etkisi vardır. Buna göre birinci hipotez kabul edilmiştir.

Korku öğesi barındıran reklamların satın alma niyeti üzerindeki etkisi ile ilgili kadınlar ve erkekler arasında olumlu veya olumsuz bir farklılaşmaya ulaşılmamıştır. Bu sonuca göre ikinci hipotez reddedilmiştir.

Araştırma sonucunda elde edilen bulgular neticesinde korku öğesi bulunduran reklamların reklama yönelik tutum üzerinde olumlu etkisinin olduğu sonucuna varılmıştır. Buna göre üçüncü hipotez kabul edilmiştir.

Korku öğesi barındıran reklamların reklama yönelik tutum üzerindeki etkisi ile ilgili kadınlar ve erkekler arasında olumlu veya olumsuz bir farklılaşmaya ulaşılmamıştır. Bu sonuca göre dördüncü hipotez reddedilmiştir.

Çalışma sonuçlarına göre bu tür reklamların satın alma niyetinde olumlu etkiye sahip olması, Snipes ve arkadaşlarının (1999: 280) çalışmasındaki bulgular ile paralellik göstermiştir. Bu tür reklamların ikna ediciliği yönüyle bakıldığında ise, çalışmanın sonuçları birçok çalışma bulguları ile uyuşmuş (Hastings vd., 2004: 978; Insko, 1965: 261; Dillard vd., 1996: 68; Tannenbaum vd., 2015: 1198; Siu, 2010: 580; Terskikh, 2017: 160; Bagozzi ve Moore, 1994: 66; Leventhal vd., 1966: 394-395; Lewis vd., 2007: 55-56; Bleakley vd., 2015: 943; Smith ve Stutts, 2003: 172; Smith ve Stutts, 2006: 281; Treise ve Weigold, 2001: 54; Bigsby vd., 2013: 11-12), bazı çalışmaların bulguları ile çelişmiştir (Jovanović, 2016: 41; Kim ve Lee, 2012: 14; Ti vd., 2017: 3).

Araştırma bulgularından anlaşıldığı üzere, korku öğesi barındıran reklamların satın alma niyeti üzerindeki etkisi ile ilgili kadınlar ve erkekler arasında olumlu veya olumsuz bir farklılaşmanın olmadığı sonucuna ulaşılmıştır. Bu sonuç, Noble ve arkadaşlarının bulguları ile çelişmiştir (2014: 6). Aynı sonuç, 
korku öğesi barındıran reklamların ikna ediciliği yönüyle ele alındığında ise, Smith ve Stutts'un çalışmasında elde edilen bulgular ile paralellik göstermiş (2003: 171), fakat çok sayıda çalışmanın bulguları ile çelişmiştir (Leventhal vd., 1966: 394-395; Tannenbaum vd., 2015: 1196; Goldenbeld vd., 2008: 213; Lewis 2007: 55-56; Samu ve Bhatnagar, 2008: 242; Smith ve Stutts, 2003: 171; Bigsby vd., 2013: 11-12).

Bu tür reklamların reklama yönelik tutumda olumlu etkilere neden olduğu sonucuna ulaşılmıştır. Bu sonuç, Snipes vd., (1999: 280), Feiz arkadaşlarının (2013: 116) bulguları ile uyuşmuş, fakat Jovanović ve arkadaşlarının (2016: 41) elde ettikleri sonuç ile çelişmiştir.

Çalışmanın amaçlarından birini oluşturan reklama yönelik tutumda cinsiyet değişkenine göre bir farklılığın olup olmadığı ile ilgili bulgularda, kadınlar ve erkekler arasında herhangi bir farka rastlanmadığı görülmüştür. Bu sonuç, Smith ve Stutts'un elde ettiği bulgular ile paralellik göstermiş (2003: 171) fakat Tannenbaum vd., (2015: 1196), Goldenbeld vd., (2008: 213) ve Noble arkadaşlarının (2014: 13) sonuçları ile çelişmiştir.

Elde edilen sonuçlar Covid-19 virüsünün toplumda çok ciddiye alınarak, pandemi döneminde reklamlarda verilen korku öğesi barındıran ve virüsten korunma temalı reklamların satın alma niyetinde ve reklama yönelik olumlu etkilerinin olduğu, cinsiyet bağlamında ele alındığında ise hem erkek hem de kadınların bu tür reklamlardan olumlu yönde etkilendikleri yani her iki cinsiyetin de virüsü ciddiye aldığı fakat birbirinden farklı düzeyde ciddiye alarak bu tür reklamlara farklı düzeyde tepkiler vermediği şeklinde yorumlanmıştır.

Çalışmada elde edilen başka bir sonuca göre ilköğretim mezunlarının lisans ve lisansüstü eğitim alan kişilere kıyasla reklama yönelik daha olumlu tutum gösterdikleri anlaşılmıştır. Snipes ve arkadaşlarının çalışmasına göre daha fazla seviyede korku öğesinin reklama yönelik daha olumlu tutuma neden olduğu sonucuna ulaşılmıştır (1999: 280). Memiş Doğan ve Düzel'in insanların Covid-19 salgınından korku, kaygı düzeylerinin araştıııldığı çalışmasında ortaöğrenim mezunlarının lisans mezunlarından daha fazla korkuya kapıldıkları sonucuna ulaşılmıştır (2020: 747). İlköğretim mezunlarının lisans ve lisansüstü mezunlarına göre Covid-19 salgınından daha fazla korkacağı ve korku seviyesi arttıkça reklama yönelik tutumun daha olumlu olduğu düşünüldüğünde, çalışmada elde edilen bu sonuç Snipes ve arkadaşlarının (1999: 280) çalışmasındaki bulgular ile uyuşmuştur

Demografik değişkenlerin tümü göz önüne alındığında reklama yönelik tutumda sadece eğitim durumu değişkenine göre bir farklılaşmanın olduğu görülmüsştür. Evli ve bekârların, farklı yaş grubunda bulunan kişilerin reklama yönelik tutumunun olumlu olduğu fakat aralarında olumlu veya olumsuz yönde bir farklılaşmanın olmadığı görülmüştür. Eğitim düzeyinde ise bir farklılaşmanın olduğu görülmüştür. Eğitim düzeyi düşük kişilerin Covid-19 virüsü ile ilgili bilimsel bilgilere ulaşma imkânlarının daha az olduğu bundan dolayı Covid-19 virüsü hakkında yanlış veya yeterli bilgilere sahip olmadıklarından virüsten daha fazla korktukları ve bunun da reklamdan daha olumlu şekilde etkilenmelerine neden olduğu düşünülmektedir.

Korku öğesi bulunduran reklamların reklama yönelik tutumda ve satın alma niyetinde olumlu etkilerinin olması nedeniyle özellikle devam eden Covid-19 döneminde bu tür reklamların daha fazla kullanılmasının işletmeler için pazarlama iletişimi amaçları bakımından fayda sağlayacağı düşünülmekte ve daha fazla kullanılması önerilmektedir.

Bu çalışmada reklama yönelik tutum ve satın alma niyeti üzerine etkiler araştırılmıştır. İleriki çalışmalarda reklamın güvenilirliğine yönelik tutum ve reklam veren markaya yönelik tutum üzerine etkiler araştırılabilir.

Deterjan, dezenfektan ve 1slak mendil gibi ürün reklamlarının etkileri araştırılmıştır. Başka çalışmalarda maske, yüz koruyucu siperlik gibi farklı fonksiyonları olan ürün reklamlarının etkilerinin araştırıldığı çalışmalar yapılabilir.

Televizyonda çıkan reklamların tüketiciler üzerindeki etkileri incelenmiştir. Başka çalışmalarda farklı mecralarda çıkan reklamların tüketiciler üzerindeki etkileri incelenebilir. 
Çalışmada korku öğesi olan reklamların etkileri araştırılmıştır. Covid-19 döneminde, virüs bitecek ve eski günlere döneceğiz veya bu zor günlerde yanınızdayız gibi korku öğesi bulundurmayan reklamlar da çok sayıda yapılmıştır. Bu tür reklamlarla ilgili çalışmalar yapılabilir.

\section{Kaynakça}

Akbulut, Y. (2010). Sosyal bilimlerde SPSS uygulamaları. İstanbul: İdeal Kültür Yayınc1l1k.

Alpar, R. (2011). Uygulamalı çok değişkenli istatistiksel yöntemler. Ankara: Detay Yayıncılık.

Aydın, İ. (2020). Karşılaştırmalı reklamların tüketicilerde neden olduğu tutum farklılıklarının araştırılması. Ekonomik ve Sosyal Araştırmalar Dergisi, 16(1), 233-255.

Aydın, İ., \& Yıldırım, İ. (2020). The effects of negative-framed antismoking public service announcements pertain to health risks on high school students. Anadolu Üniversitesi Sosyal Bilimler Dergisi, 20(2), 29-44.

Bagozzi, R. P., \& Moore, D. J. (1994). Public service advertisements: emotions and empathy guide prosocial behavior. Journal of marketing, 58(1), 56-70.

Barone, M. J., \& Miniard, P. W. (1999). How and when factual ad claims mislead consumers: examining the deceptive consequences of copy x copy interactions for partial comparative advertisements. Journal of Marketing Research, 36(1), 58-74.

Baydaş, A. \& Yaşar, M. E. (2020). Reklam etkinliğinin tüketici perspektifinden değerlendirilmesi. Bingöl Üniversitesi Sosyal Bilimler Enstitüsü Dergisi, (19), 179-206.

Bigsby, E., Cappella, J. N., \& Seitz, H. H. (2013). Efficiently and effectively evaluating public service announcements: additional evidence for the utility of perceived effectiveness. Communication Monographs, 80(1), 1-23.

Bleakley, A., Jordan, A. B., Hennessy, M., Glanz, K., Strasser, A., \& Vaala, S. (2015). Do emotional appeals in public service advertisements influence adolescents' intention to reduce consumption of sugar-sweetened beverages?. Journal of Health Communication, 20(8), 938-948.

Chang, C. (2007). The relative effectiveness of comparative and noncomparative advertising: evidence for gender differences in information-processing strategies. Journal of Advertising, 36(1), 21-35.

Dillard, J. P., Plotnick, C. A., Godbold, L. C., Freimuth, V. S., \& Edgar, T. (1996). The multiple affective outcomes of AIDS PSAs: fear appeals do more than scare people. Communication research, 23(1), 44-72.

Feiz, D., Fakharyan, M., Jalilvand, M. R., \& Hashemi, M. (2013). Examining the effect of tv advertising appeals on brand attitudes and advertising efforts in Iran. Journal of Islamic Marketing, 4(1), 101125.

Glascoff, D. W. (2000). A meta-analysis of fear appeals: implications for effective public health campaigns. Marketing Health Services, 20(4), 35.

Goldenbeld, C., Twisk, D., \& Houwing, S. (2008). Effects of persuasive communication and group discussions on acceptability of anti-speeding policies for male and female drivers. Transportation Research Part F: Traffic Psychology and Behaviour, 11(3), 207-220.

Hastings, G., Stead, M., \& Webb, J. (2004). fear appeals in social marketing: strategic and ethical reasons for concern. Psychology \& Marketing, 21(11), 961-986.

Insko, C.A., Arkoff, A., \& Insko, V. M. (1965). Effects of high and low fear-arousing communications upon opinions toward smoking. Journal of Experimental Social Psychology, 1(3), 256-266. 
Jain, V., Trivedi, R., Joshi, V., \& Daswani, A. (2012). Does explicit comparative advertising affect indian consumers' attitudes towards low and high-1nvolvement product. International Journal of Emerging Markets, 10(1), 122-140.

Jovanović, P., Vlastelica, T., \& Kostić, S. C. (2016). Impact of advertising appeals on purchase intention. Management: Journal of Sustainable Business and Management Solutions in Emerging Economies, 21(81), 35-45.

Kim, H., \& Lee, C. (2012). Differential effects of fear-eliciting DTCA on elaboration, perceived endorser credibility, and attitudes. International Journal of Pharmaceutical and Healthcare Marketing, 6(1), 4-22.

Krejcie, R. V., \& Morgan, D. W. (1970). Determining sample size for research activities. Educational and Psychological Measurement, 30, 607-610.

Leventhal, H., Jones, S., \& Trembly, G. (1966). Sex differences in attitude and behavior change under conditions of fear and specific instructions. Journal of Experimental Social Psychology, 2(4), 387-399.

Lewis, I., Watson, B., \& Tay, R. (2007). Examining the effectiveness of physical threats in road safety advertising: the role of the third-person effect, gender, and age. Transportation Research Part F: Traffic Psychology and Behaviour, 10(1), 48-60.

Memiş Doğan, M., \& Düzel, B. (2020). Covid-19 özelinde korku-kaygı düzeyleri. Turkish Studies, 15(4), 739-752.

Neese, W. T., Foxx, W., \& Eppler D. B. (2019). The effectiveness of comparative advertising in the US automobile market influenced by consumer ethnocentrism, industry-specific personal characteristics, and foreign versus domestic brand ownership. Journal of Global Scholars of Marketing Science, 29(1), 114-128.

Noble, G., Pomering, A., \& Johnson, L. W. (2014). Gender and message appeal: their influence in a pro-environmental social advertising context. Journal of Social Marketing, 4(1), 4-21.

O'Donoghue, A. C., Williams, P. A., Sullivan, H. W., Boudewyns, V., Squire C., \& Willoughby J. F. (2014). Effects of comparative claims in prescription drug direct-to-consumer advertising on consumer perceptions and recall. Social Science \& Medicine, 120, 1-11.

Pornpitakpan, C., \& Yuan, Y. (2015). Effects of perceived product similarity and ad claims on brand responses in comparative advertising. Asia Pacific Journal of Marketing and Logistics. 27(4), 535-558.

Samu, S., \& Bhatnagar, N. (2008). The efficacy of anti-smoking advertisements: the role of source, message, and individual characteristics. International Journal of Nonprofit and Voluntary Sector Marketing, 13(3), 237-250.

Sanbonmatsu, D. M., \& Kardes, F. R. (1988). The effects of physiological arousal on information processing and persuasion. Journal of Consumer Research, 15(3), 379-385.

Shimp, T. A. \& Andrews, J. C. (2013). Advertising, promotion, and other aspects of integrated marketing communications. Mason: Cengage Learning.

Siu, W. (2010). Fear appeals and public service advertising: applications to influenza in hong kong. Health Communication, 25(6-7), 580-580.

Smith, K. H., \& Stutts M. A. (2003). Effects of short-term cosmetic versus long-term health fear appeals in anti-smoking advertisements on the smoking behaviour of adolescents. Journal of Consumer Behaviour , 3(2), 157-177. 
Smith, K. H., \& Stutts M. A. (2006). The influence of individual factors on the effectiveness of message content in antismoking advertisements aimed at adolescents. The Journal of Consumer Affairs, 40(2), 261-293.

Snipes, R. L., Latour, M. S., \& Bliss, S. J. (1999). A model of the effects of self-efficacy on the perceived ethicality and performance of fear appeals in advertising. Journal of Business Ethics, 19(3), 273285.

Stevens, J. P. (2009). Applied multivariate statistics for the social sciences. New York: Routledge, Taylor \& Francis Group.

Tabachnick B. G., \& Fidell, L. S. (2015). Çok değişkenli istatistiklerin kullanımı. (M. Baloğlu vd., Çev.) Ankara: Nobel Akademik Yayıncılık Eğitim Danışmanlık Tic. Ltd. Şti.

Tannenbaum, M. B., Hepler, J., Zimmerman, R. S., Saul, L., Jacobs, S., Wilson, K., \& Albarracín, D. (2015). appealing to fear: a meta-analysis of fear appeal effectiveness and theories. Psychological bulletin, 141(6), 1178.

Terskikh, M. V. (2017). Humor and fear appeals in public service announcements discourse. Вопросы когнитивной лингвистики, (3), 52.

Ti, L., Fast, D., Small, W., \& Kerr, T. (2017). Perceptions of a drug prevention public service announcement campaign among street-1nvolved youth in Vancouver, Canada: a qualitative study. Harm reduction journal, 14(1), 1-8.

Treise, D., \& Weigold, M. F. (2001). AIDS public service announcements: effects of fear and repetition on predictors of condom use. Health Marketing Quarterly, 18(3-4), 39-61.

Witte, K., \& Allen, M. (2000). A meta-analysis of fear appeals: implications for effective public health campaigns. Health education \& behavior, 27(5), 591-615.

Williams, K. C. (2012). Fear appeal theory. Research in Business and Economics Journal, 5(1), 1-21.

https://www.lumen-research.com/blog/corona-related-ads-get-9-more-attention (Erişim: 01.10.2020). 


\section{Extended Abstract}

During the Covid-19 pandemic period, the topics that human health is under threat were covered in the advertisements and fear elements were frequently used by the companies. During the pandemic period, almost all consumers were exposed to numerous advertisements with a fear element, such as, if you use this detergent, disinfectant or wet wipe, you can protect yourself from the virus, if you do not use it, increases your risk of catching the virus. The aim of this study is to investigate how the anti protection themed advertisements on television during the Covid-19 pandemic period will affect the purchase intention and attitude towards the advertisement. While investigating these effects, it will also be examined whether there is any difference between demographic differences by considering the variables of gender, age, education level, and marital status. With the covid-19 pandemic affecting the business world, marketing activities, almost everything in the world and the lives of all people, it is think important to investigate the effects of virus protection themed and fear appeal advertisements on purchase intention and advertising in such a period considered to have significant contributions. In addition, the literature was examined in detail and no study was found that investigated the effects of the fear appeal and virus protection themed ads on purchase intention and attitude towards the ad during the Covid-19 period. It is thought that carry out such a study for the first time will also make the study more valuable.

Stronger fear elements cause more attitude, intention, and behavior changes (Witte and Allen, 2000: 598). In a study by Snipes et al. on 305 women, it was revealed that participants who watched advertisements with high fear elements were more likely to purchase than those who watched low fear elements (1999: 280). In most studies, it has been concluded that advertisements containing fear appeals are more persuasive for women than men (Lewis 2007: 55-56; Samu and Bhatnagar, 2008: 242; Smith and Stutts, 2003: 171; Bigsby et al., 2013: 11-12). In the study of Snipes et al., it was revealed that participants who watched advertisements with high fear elements were more positively affected by the attitude towards the advertisement than those who watched low degree fear elements (1999: 280). In the study conducted by Tannenbaum et al., in the form of meta-analysis, it was concluded that the advertisements containing the fear element in the attitude variable were more effective in women than in men (2015: 1196).

The universe of this study consists of people who live in Turkey and have been exposed to virus protection themed advertisements that contain a fear element on television during the Covid-19 Pandemic period. The link of the questionnaire was sent to many people living in Turkey via Whatsapp, one of the social media applications, and the people who were sent were requested to send it to their acquaintances. The sample of the study consists of 756 people reached by snowball sampling method.

The Cronbach's alpha value for the scale used in the study was found to be, 893 . According to this value, the scale has high reliability. The factor structure of the scale was determined by using the Direct Oblimin method, which is one of the principal component analysis and oblique rotation methods. As a result of these procesess, a 2 -factor structure was obtained, which explains $81,951 \%$ of the total variance. It was determined that each of the sub-factors explained more than $5 \%$ of the total variance. Accordingly, the construct validity of the scale was ensured. One-way MANOVA, one-factor ANOVA, and one-sample t test were used to analyze the data obtained.

It is considered to be very valuable in many respects to reach the conclusions that the use of the virus, which caused this extraordinary period, as an element of fear in advertisements, has positive, negative effects or does not cause any effect on consumers' purchase intention and attitude towards advertising. According to the results obtained, advertisements with fear elements have a positive effect on purchase intention. There was no positive or negative difference between men and women regarding the effect of fear appeal advertisements on purchase intention. It was concluded that the advertisements containing the fear element had a positive effect on the attitude towards the advertisement. In addition, no positive or negative difference was found between men and women regarding the effect of fear appeal advertisements on attitude towards advertisements.

According to the results of the study, the positive effect of such advertisements on purchase intention was similar to the findings of the study of Snipes et al. (1999: 280). In terms of the persuasiveness of such advertisements, the results of the study agree with the findings of many studies (Hastings et al., 2004: 978; Dillard et al., 1996: 68; Bagozzi and Moore, 1994: 66;Lewis et al., 2007: 55-56; Bleakley et al., 2015: 943; Smith and Stutts, 2003 : 172; Smith and Stutts, 2006: 281; Treise and Weigold, 2001: 54; Bigsby et al., 2013: 11-12), which contradicted the findings of some studies (Jovanović, 2016: 41; Ti et al., 2017: 3).

It has been concluded that there is no positive or negative difference between men and women regarding the effect of fear appeal advertisements on purchase intention. This result contradicted the findings of Noble et al. (2014: 6). The same result, when considered in terms of the persuasiveness of the advertisements containing the fear element, showed parallelism with the findings obtained in the study of Smith and Stutts (2003: 171), but it 
contradicted the findings of many studies (Tannenbaum et al., 2015: 1196; Goldenbeld et al., 2008: 213; Lewis 2007: 55-56; Samu and Bhatnagar, 2008: 242; Smith and Stutts, 2003: 171; Bigsby et al., 2013: 11-12).

It has been concluded that such advertisements cause positive effects on the attitude towards the advertisement. This result agreed with the findings of Snipes et al., (1999: 280), Feiz et al. (2013: 116), but contradicted the results obtained by Jovanović et al. (2016: 41).

In the findings about whether there is a difference according to the gender variable in the attitude towards advertising, which is one of the aims of the study, it was seen that there was no difference between women and men. This result showed parallelism with the findings of Smith and Stutts (2003: 171) but contradicted the results of Tannenbaum et al., (2015: 1196), Goldenbeld et al., (2008: 213) and Noble et al., (2014: 13).

According to another result obtained in the study, it was understood that primary school graduates showed more positive attitudes towards advertising compared to those who received undergraduate and graduate education. According to the study of Snipes et al., it was concluded that higher levels of fear element cause a more positive attitude towards the advertisement (1999: 280). In the study of Memiş Doğan and Düzel, which investigated the fear and anxiety levels of people from the Covid-19 pandemic, it was concluded that secondary school graduates are more afraid than undergraduate graduates (2020: 747). Considering that primary school graduates will be more afraid of the Covid-19 pandemic compared to undergraduate and graduate graduates, and the attitude towards advertising is more positive as the level of fear increases, this result obtained in the study is consistent with the findings in the study of Snipes et al., (1999: 280).

Considering all of the demographic variables, it was observed that there was a difference in the attitude towards advertising only according to the variable of educational status. It has been observed that the attitudes of married and single people, people in different age groups, towards advertising are positive, but there is no positive or negative difference between them. It has been observed that there is a difference in education level. It is thought that people with a low level of education have less opportunity to access scientific information about the Covid19 virus, so they are more afraid of the virus because they do not have false or sufficient information about the Covid-19 virus, and this causes them to be more positively affected by advertisements.

Since advertisements with fear elements have positive effects on the attitude towards the advertisement and purchase intention, it is thought that the use of such advertisements more especially in the ongoing Covid-19 period will be beneficial for businesses in terms of marketing communication purposes and it is recommended to use them more.

In this study, the effects on attitude towards advertising and purchase intention were investigated. In future studies, the effects on the attitude towards the reliability of the advertisement and the attitude towards the advertiser brand can be investigated.

The effects of product advertisements such as detergent, disinfectant, and wet wipes were investigated. In other studies, studies can be conducted to investigate the effects of product advertisements with different functions such as masks and face shields.

The effects of advertisements on television on consumers were examined. In other studies, the effects of advertisements in different media on consumers can be examined.

In the study, the effects of advertisements with fear elements were investigated. In the Covid-19 period, there have been many advertisements that do not contain a fear element, such as the virus will end and we will return to the old days or we are with you in these difficult days. Studies on such advertisements can be made. 